\title{
PKA functions in metabolism and resistance to obesity: lessons from mouse and human studies
}

\author{
Edra London, Michelle Bloyd and Constantine A Stratakis \\ Section on Endocrinology and Genetics, Eunice Kennedy Shriver National Institute of Child Health and Human Development, National Institutes of Health, \\ Bethesda, Maryland, USA
}

Correspondence should be addressed to E London: edra.Iondon@nih.gov

This article is based on the presentation for the 2019 Society for Endocrinology Dale Prize Lecture at SfE BES 2019 meeting, 11 November 2019 , Brighton, UK

\begin{abstract}
Both direct and indirect evidence demonstrate a central role for the CAMP-dependent protein kinase (PKA) signaling pathway in the regulation of energy balance and metabolism across multiple systems. However, the ubiquitous pattern of PKA expression across cell types poses a challenge in pinpointing its tissue-specific regulatory functions and further characterizing its many downstream effects in certain organs or cells. Mouse models of PKA deficiency and over-expression and studies in living cells have helped clarify PKA function in adipose tissue (AT), liver, adrenal, pancreas, and specific brain nuclei, as they pertain to energy balance and metabolic dysregulation. Limited studies in humans suggest differential regulation of PKA in AT of obese compared to lean individuals and an overall dysregulation of PKA signaling in obesity. Despite its complexity, under normal physiologic conditions, the PKA system is tightly regulated by changes in CAMP concentrations upstream via adenylate cyclase and downstream by phosphodiesterase-mediated CAMP degradation to AMP and by changes in PKA holoenzyme stability. Adjustments in the PKA system appear to be important to the development and maintenance of the obese state and its associated metabolic perturbations. In this review we discuss the important role of PKA in obesity and its involvement in resistance to obesity, through studies in humans and in mouse models, with a focus on the regulation of PKA in energy expenditure, intake behavior, and lipid and glucose metabolism.
\end{abstract} Key Words:

\section{Introduction}

Since the early 1990s, obesity has been recognized as a complex, multifactorial disease in which genetics is one of the key factors (Bray 1992, Vogler et al. 1995). Our knowledge about the complex mechanisms underlying the imbalance between energy intake and expenditure continues to evolve, particularly with the use of genetic and optogenetic methodologies, yet it is still not well understood why some individuals are more susceptible to obesity than others (Brownell \& Wadden 1992, Kim et al. 2018). Rare monogenic forms of obesity have facilitated much of our understanding about key molecular pathways involved in maintaining energy balance. Most of these regulatory pathways involve cyclic AMP (cAMP) signaling.

The cAMP-dependent protein kinase (PKA) enzyme is essential for intracellular signal transduction and in the maintenance of cellular homeostatic processes 
(Krebs 1972) by potentiating the signals from a wide range of ligands that bind G-protein coupled receptors (GPCRs) and activate the G $\alpha \beta \gamma$ heterotrimer to release the $\mathrm{G}_{\mathrm{s}} \alpha$ subunit that, in turn, binds to and activates adenylate cyclase and generates intracellular cAMP. PKA is therefore integral in regulating a great many cellular functions in diverse cell types.

The PKA holoenzyme is a tetramer assembled from two regulatory and two catalytic subunits comprised of different combinations of the PKA regulatory (RI $\alpha$, RII $\alpha$, RI $\beta$, and RII $\beta)$ and catalytic (C $\alpha, C \beta, C \gamma$, and PRKX) subunits, typically involving two identical pairs of a regulatory and a catalytic subunit. Each PKA subunit has a unique, tissue-specific pattern of expression (Corbin et al. 1975). Type I (RI $\alpha$ and RI $\beta$ ) regulatory subunits vs type II (RII $\alpha$ an RII $\beta$ ) regulatory subunit holoenzyme composition impacts PKA holoenzyme affinity for cAMP as well as its cellular localization, primarily via A-kinase anchoring proteins (AKAPs) (Feliciello et al. 2001) (Fig. 1). The ratio of type I to type II PKA activity can vary dramatically among tissues and species (Corbin \& Keely 1977). Mouse studies have shown unequivocal specificity in PKA subunit expression across neural regions that suggest differences in PKA function that are likely mediated by the unique biochemical properties of the different isoforms (Cadd \& McKnight 1989).

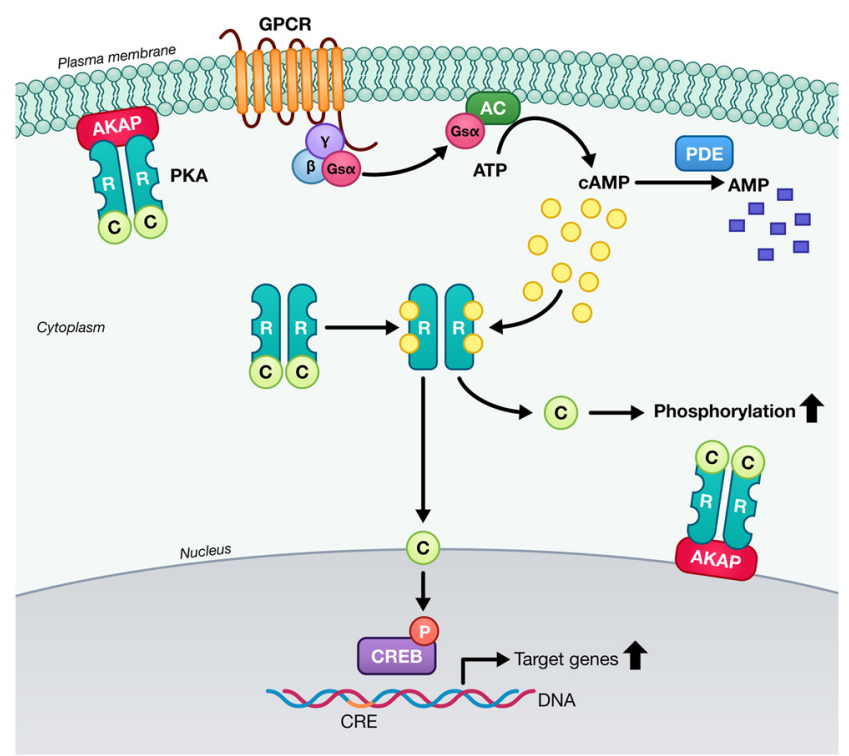

\section{Figure 1}

Diagram of intracellular PKA signaling. AC, adenylate cyclase; AKAP, A-kinase anchoring protein; AMP, adenosine monophosphate; ATP, adenosine triphosphate; C, PKA catalytic subunit; CAMP, cyclic adenosine monophosphate; CREB, CAMP-response element binding protein; GPCRs, G-protein coupled receptors; PDE, phosphodiesterase; R, PKA regulatory subunit.
Activation of the PKA holoenzyme by cAMP binding at two sites on each regulatory subunit initiates the release of the catalytic subunits, thereby activating the catalytic subunits and enabling two distinct modes of regulation: cytoplasmic phosphorylation of its targets and translocation of the catalytic subunit to the nucleus where it exerts transcriptional regulation (Adams et al. 1991), largely through cAMP-response element binding protein (CREB) family phosphorylation (Gonzalez \& Montminy 1989) (Fig. 1).

Defects or altered expression of one PKA subunit can lead to compensatory changes in the other subunits at the protein level. RI $\alpha$ is known to be the most critical mediator of regulated PKA activity in living systems (Amieux \& McKnight 2002). Pulse-chase experiments in cell culture showed that the half-life of the RI $\alpha$ subunit increased over four times when assembled as part of the holoenzyme compared to unbound (Amieux et al. 1997) demonstrating the impact of subunit stability on enzymatic activity potential. Destabilization of the $\mathrm{C} \alpha$ subunit upon its release from the holoenzyme has also been demonstrated to cause notable decreases in both protein concentration and PKA activity (Garrel et al. 1995). We have seen that the effects of subunit disruption vary from tissue to tissue, presumably because of the unique expression profiles of each PKA subunit and the subsequent abilities to compensate for these changes among different cell types. Considering its known role in regulating hormone secretion and hormone action downstream of PKA by phosphorylation, it is not surprising that the PKA-axis plays a central role in metabolism and energy balance.

\section{Dynamic regulation of the PKA system}

Molecular genetic techniques have enabled the generation of mouse models to investigate the specificity and relative importance of the different PKA subunits. Disruption of the genes coding for each PKA subunit have been individually studied in mice (Brandon et al. 1995, Cummings et al. 1996, Burton et al. 1997, Amieux et al. 2002, Howe et al. 2002, Skalhegg et al. 2002) (Table 1). Deletion of either the protein kinase cAMP-activated type 1 regulatory subunit alpha (Prkar1a) or protein kinase cAMP-activated catalytic subunit alpha (Prkaca) genes caused embryonic lethality (Amieux et al. 2002). Additionally, the concept that each PKA subunit has unique non-redundant functional properties has emerged.

Compensation for defects in PKA signaling is primarily accomplished by changes in PKA holoenzyme 
Table 1 Summary of mouse models of altered PKA subunit expression and their associated phenotypes.

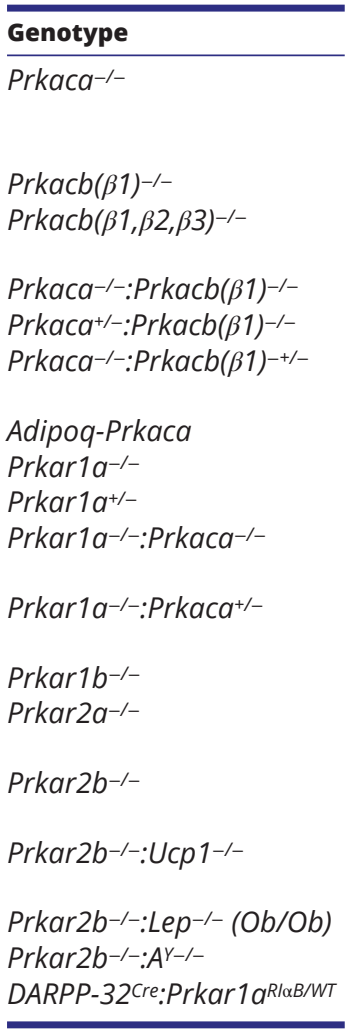

\begin{tabular}{l} 
Phenotype \\
\hline Perinatal lethality in 73\% offspring, survival dependent on \\
background and environment; surviving mice had growth \\
deficits, male infertility \\
Deficiencies in contextual learning \\
Resistant to DIO, sympathetic nervous system alterations with \\
numerous sex-dependent characteristics \\
Embryonically lethal \\
Defects in neural tube development \\
Gestationally lethal; all pups had neural tube development \\
defects, some had exencephaly \\
Resistant to DIO, increased BAT UCP1 induction \\
Embryonically lethal \\
Tumorgenesis associated with CNC \\
Embryonically lethal with significant cardiac abnormalities \\
Embryonically lethal with better (but still poor) \\
cardiac status \\
Deficiencies in memory and synaptic plasticity \\
Resistant to DIO and steatohepatitis, improved glucose \\
sensitivity \\
Resistant to DIO, insulin resistance and increased nocturnal \\
activity \\
Maintenance of lean phenotype and increased nocturnal \\
activity \\
Obese phenotype rescued \\
Obese phenotype rescued \\
Growth retardation; hypophagic, lean, resistant to DIO \\
\hline
\end{tabular}

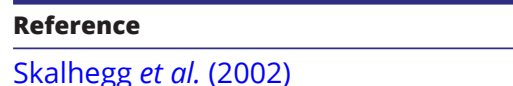

Qi et al. (1996)

Enns et al. (2009), London et al. (2019)

Huang et al. (2002)

Huang et al. (2002)

Huang et al. (2002)

Dickson et al. (2016)

Amieux et al. (2002)

Kirschner et al. (2005)

Amieux et al. (2002),

Kirschner et al. (2005)

Amieux et al. (2002)

Brandon et al. (1995)

London et al. (2014a)

Brandon et al. (1995), Schreyer et al.

(2001), Nolan et al. (2004)

Nolan et al. (2004)

Newhall et al. (2005)

Czyzyk et al. (2008)

Yang et al. (2014) or catalytic subunit stability and not by transcriptional or translational modulation, which is often achieved by the enhanced half-life of PKA subunit RI $\alpha$ upon its incorporation into the holoenzyme (Amieux et al. 1997). More generally, regulation of intracellular PKA action in response to perturbations in the system occurs by changes in the stability of the holoenzyme and affinity for cAMP that are subunit specific (Otten et al. 1991). Further, we have seen that, in the presence of PKA subunit defects, one normal allele (heterozygosity) can be sufficient to maintain normal PKA enzymatic activity (Willis et al. 2011). Despite conserved domain organization among the PKA isoforms, small-angle x-ray scattering has revealed distinct quaternary structures for the different PKA holoenzyme isoforms (Heller et al. 2004, Vigil et al. 2006) that impact how the enzyme complex associates and dissociates (Zhang et al. 2012). The notion of non-redundancy among the isoforms is evidenced by the differential metabolic impacts of defects in the different PKA subunits that are later described in this review.

\section{Dysregulation of PKA signaling in obesity: observations in humans and mice}

\section{Human obesity}

Though sparse, a few studies in humans have shown differences in the PKA signaling system in obese compared to lean individuals. PRKAR2B mRNA was decreased in visceral and s.c. adipose tissue (AT) from obese compared to lean individuals, and PRKAR2B levels were inversely related to circulating insulin and homeostasis model assessment of insulin resistance as well as BMI and waist circumference (Mantovani et al. 2009). Another study of lean and obese, non-diabetic, non-hyperlipidemic males revealed the downregulation of genes involved in lipolysis in s.c. AT, including PRKAR $2 B$ and A-kinase anchoring protein 1 (AKAP1) (Marrades et al. 2010) that were independent of differences in intake or activity level. In another investigation, PKA-dependent skeletal muscle lipolysis was blunted via hormone-sensitive lipase (HSL) phosphorylation on PKA sites Ser ${ }^{563}$ and Ser659 in a cohort of obese compared to lean men (Jocken et al. 2008). 


\section{The role of PKA signaling in Cushing syndrome (CS)}

PKA activation is the primary mediator of cortisol secretion in adrenocortical cells (Fig. 2). Somatic or germline mutations in the genes that code for molecules in the PKA signaling pathway are frequently associated with hypercortisolemia. CS is caused by elevated circulating glucocorticoids and leads to central obesity. Clinical features of CS include weight gain, hypertension, diabetes mellitus, osteoporosis, proximal muscle weakness, striae, and decreased growth velocity in children. There have been several thorough reviews of the genetics of CS that reported on the discovery of many gene variants associated with cortisol-producing adenomas and hyperplasias (Espiard et al. 2014, Lodish \& Stratakis 2016). Briefly, activating mutations in PKA signaling molecules or inactivating mutations in molecules that inhibit the PKAsignaling pathway cause hypercortisolemia. For example, activating mutations in guanine nucleotide-binding protein $\mathrm{G}(\mathrm{s})$ subunit alpha (GNAS) are associated with cortisol-secreting tumors in McCune-Albright syndrome (Weinstein et al. 1991). Somatic activating mutations in PRKACA were found in cortisol-producing adenomas
(Beuschlein et al. 2014), and inactivating mutations of PRKAR1A cause Carney complex (Kirschner et al. 2000) and a rare form of adrenocortical hyperplasia called primary pigmented nodular adrenocortical disease (Groussin et al. 2002). Inactivating mutations in phosphodiesterases (PDEs), specifically PDE8B and PDE11A, lead to elevated cAMP levels and aberrant PKA activity (Horvath et al. 2008a,b).

Despite the common endpoint of hypercortisolemia, the various PKA subunit mutations yield a distinct phenotype in line with the specificity of function inherent in each PKA subunit and are associated with differences in adiposity and distribution of AT (London et al. 2014b). CS occurs much more frequently in women than in men, which highlights the existing sexual dymorphism in PKA regulation of energy balance and adiposity that is also a feature of PKA mouse models (Stratakis 2008).

\section{Obesity in rodents}

Mouse studies have provided significant mechanistic insight into PKA dysregulation in the obese state. In obesity, AT remodeling and expansion vary and impact the

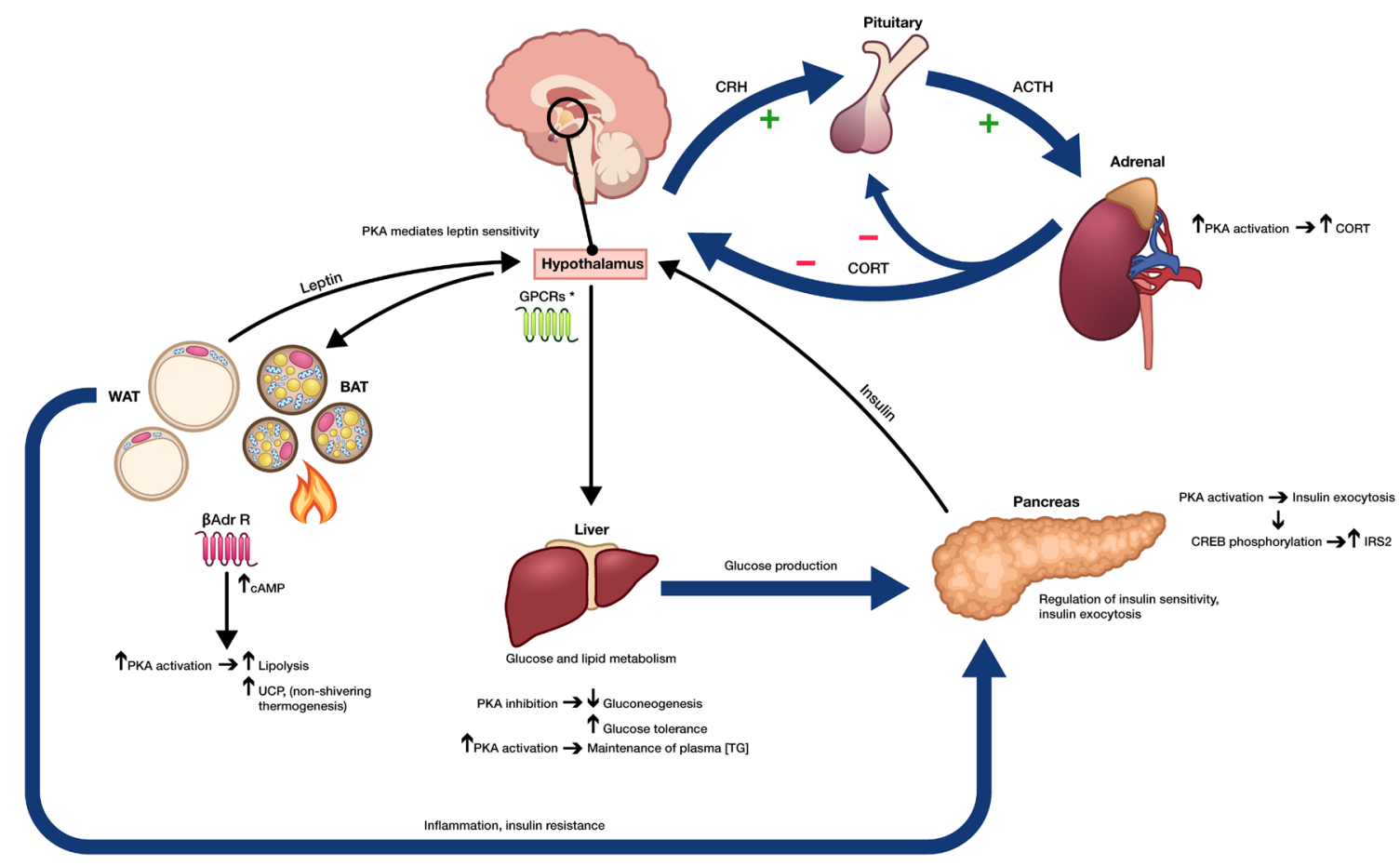

Figure 2

Overview of the integrated central and peripheral regulation of metabolism and energy balance by the PKA signaling system. *The hypothalamus and other brain regions regulate neural systems important to energy balance as well as peripheral organs such as AT, liver, and gut through multiple GPCRs linked to PKA signaling; the graph is simplified given the many factors and complicated interactions that include but are not limited to POMC, NPY, BDNF, and their receptors from the melanocortin family (MC2R, MC3R, and MC4R). ACTH, adrenocorticotropic hormone; BAT, brown adipose tissue; CAMP, cyclic adenosine monophosphate; $\mathrm{CRH}$, corticotropin-releasing hormone; CORT, cortisol; TG, triglycerides; WAT, white adipose tissue. 
susceptibility to metabolic disease. Ultimately, differences in distribution of AT and adipogenesis impact AT function and physiology, beyond the expansion of adipocytes and increased lipid content, and can be a key determinant of metabolic health (Vishvanath \& Gupta 2019). In WAT from diet-induced obese rats, cAMP concentration, PKA and HSL activity, and perilipin phosphorylation were all decreased. Further, isoproterenol-stimulated lipolysis was decreased and $\beta 1$ - and $\beta 3$-adrenergic receptors were downregulated in obese compared to WT animals (Ding et al. 2016). There is increasing evidence that depot specific WAT-brain circuitry is crucial for regulating lipolysis, energy expenditure, and the maintenance of energy homeostasis (Bartness et al. 2014).

The PKA signaling response to the fasted state is significantly altered in obese compared to lean mice. In WAT, fasting-induced activation of PKA was impaired in obese rats and this was associated with altered lipid and carbohydrate metabolism in AT (Flores-Opazo et al. 2019). In the fasted state, CREB phosphorylation was impaired in the dorsomedial hypothalamus (DMH) of obese mice compared to the robust induction of CREB observed in lean-fasted mice. In the arcuate nucleus, phosphorylated CREB (pCREB) levels were high in both fed and fasted states in obese mice, whereas lean mice had substantial CREB induction only during fasting, which is likely to impact feeding behavior (London et al. 2017). Others have reported that high-fat diet (HFD) feeding caused decreased hypothalamic PKA signaling that was accompanied by elevated PDE4A levels in obese mice that exhibited a depression-like behavioral phenotype (Vagena et al. 2019).

\section{Resistance to diet-induced obesity (DIO) in mouse models of PKA subunit deficiency}

\section{The Prkar2b knockout (RII/KO) mouse}

The regulatory subunit II $\beta$ is expressed highly in brain and in AT and is modulated throughout embryonic development in several other tissues (McKnight et al. 1988). This expression pattern has led to extensive characterization of the role of RII $\beta$ in the regulation of adiposity, thermogenesis, and energy balance in mice. See Table 1 for a summary of PKA mouse models. Disruption of the Prkar $2 b$ gene that codes for PKA RII $\beta$ caused a lean phenotype and resistance to DIO in mice (Cummings et al. 1996). RII $\beta K O$ mice had fat-pad weights half that of WT littermates and decreased adipocyte size and number in white AT (WAT). In brown AT (BAT), the disruption of RII $\beta$ initiated an isoform switch from RII $\beta$ to RI $\alpha$, thereby causing a five-fold increase in basal PKA activity and similar increases in uncoupling protein-1 (UCP1) (Cummings et al. 1996, Planas et al. 1999). Alterations in glucose regulation and neural control of energy balance in RIIßKO mice are discussed in detail later in this review.

\section{The Prkar2a KO (RIloKO) mouse}

Deficiency of the PKA type 2 regulatory subunit alpha conferred resistance to DIO obesity despite the lack of phenotype when mice were maintained on a normal chow diet that was low in fat ( $6 \%$ fat by weight) (Burton et al. 1997, London et al. 2014a). RIIoKO mice had decreased hepatic PKA activity after HFD feeding and decreased hepatic steatosis, but unlike the RII $\beta K O$ mouse, RII $\alpha \mathrm{KO}$ mice did not have marked increases in oxygen consumption that could explain the observed DIO resistance. Instead, it appears that the low, but very specific, brain expression of RII $\alpha$ in habenula originally identified by McKnight and colleagues is likely responsible for alterations in intake behavior specifically of rewarding sweet and high-fat foods (Cadd \& McKnight 1989; London E, Bloyd M \& Stratakis CA, unpublished observations). RII $\alpha$ KO mice also resisted diet-induced glucose dysregulation and maintained superior insulin sensitivity compared to that of WT littermates after chronic HFD feeding (London et al. 2014a).

\section{The Prkarcb KO (C $\beta \mathrm{KO})$ mouse}

The protein kinase cAMP-activated catalytic subunit beta (Prkarcb) has three isoforms (C1, C2, and C3), the last two of which are transcribed exclusively from neural promoters (Guthrie et al. 1997, Desseyn et al. 2000). Mice deficient for all three isoforms of $\mathrm{C} \beta$ had decreased PKA enzymatic activity in brain (Howe et al. 2002), were genetically lean, and resisted DIO (Enns et al. 2009, London et al. 2019). C $\beta K O$ mice also resisted hepatic steatosis, dyslipoproteinemia, and had improved glucose and insulin sensitivity (Enns et al. 2009). Growth curves revealed sex-specific differences in body mass as male but not female $\mathrm{C} \beta \mathrm{KO}$ mice maintained on a normal chow diet had decreased body weight compared to WT mice from young adulthood that appeared to be primarily due to decreased lean body mass (London et al. 2019). Male C $\beta \mathrm{KO}$ mice had a significantly elevated oxygen consumption rate and female mice exhibited increased home cage locomotor activity. A major feature of the lean, DIO-resistant C $\beta \mathrm{KO}$ mouse phenotype was elevated 
heart rate and in females elevated s.c. body temperature that was due to centrally mediated increased sympathetic outflow. In line with this finding, C $\beta \mathrm{KO}$ mice had denser mitochondria and increased UCP1 in brown adipocytes, evidence of increased $\beta 3$-adrenergic activation of BAT (London et al. 2019).

\section{Central regulation of energy balance by PKA: hunger, satiety, and energy expenditure}

\section{PKA and regulation of the neuropeptide Y (NPY)/ agouti-related protein (AgRP) and proopiomelanocortin (POMC) system}

The leptin-deficient $o b / o b$ mouse is a well-studied model of monogenic obesity characterized by hyperphagia, hyperinsulinemia, decreased locomotor activity, defective BAT activation, and excessive adiposity (Zhang et al. 1994). The $o b / o b$ mouse has enabled deeper insight into the central regulation of energy homeostasis and the NPY/AgRP and POMC system. The adipocyte-derived hormone leptin, dubbed a 'satiety factor', is a sensor of lipid stores that exerts control over intake behavior, perceived hunger, and endocrine function via the melanocortin system in the arcuate nucleus of the hypothalamus. Leptin acts via inhibition and stimulation of the $O B R b$ receptors on two sets of opposing neurons, NPY/AgRP orexigenic neurons and pro-opiomelanocortin (POMC)/cocaine and amphetamine-related transcript (CART) anorexigenic neurons, that stimulate or inhibit feeding, respectively (Elias et al. 1999, Elmquist et al. 1999). For an in-depth review see Schwartz et al. (2000).

PKA is an integral mediator of this dichotomous hypothalamic system at multiple junctions because GPCRs mediate the actions of the primary targets of NPY and melanocortin: thyrotropin-releasing hormone (TRH), melanin-concentrating hormone $(\mathrm{MCH})$, and gamma-aminobutyric acid (GABA) neurons (Fig. 2). TRH, melanocortin 4 receptor (MC4R), and MC3R act via $\mathrm{G}_{\mathrm{s}} \alpha$, while the GABA receptor acts through $\mathrm{Gi} / \mathrm{Go}$. The TRH gene is regulated by overlapping thyroid response and cAMP response elements, and enhanced CREB phosphorylation caused robust TRH promoter stimulation that was further amplified by co-expression of a constitutively activated PKA construct (Wilber \& Xu 1998). MC4R internalization in response to an agonist was shown to be dependent upon PKA or G-protein-coupled receptor kinase and was partially inhibited by pretreatment with H89, a specific PKA inhibitor (Shinyama et al. 2003). MCR stimulation leads to increased cAMP concentrations and activation of PKA (Kim et al. 2002).

Intact hypothalamic PKA/CREB signaling is necessary to maintain energy homeostatic processes in mice (Fig. 2). Inhibition of CREB binding protein (Cbp) by AAVmediated ventromedial hypothalamic Cre expression in $C b f^{f l o x} / f l o x$ mice increased food intake, decreased body temperature, and led to decreased Pomc and brainderived neurotrophic factor (Bdnf) mRNA expression (Moreno et al. 2016). Also, important to the regulation of energy and glucose homeostasis are orexin peptides A and B that signal through the GPCRs orexin receptors 1 and 2 (OX1R and OX2R) and therefore are regulated downstream by PKA signaling and CREB transcriptional activity. Orexin deficiency in mice results in obesity (Hara et al. 2001), age-related glucose intolerance, and insulin insensitivity (Tsuneki et al. 2008). OX1R and OX2R in lateral hypothalamus (LH) project throughout the CNS including major projections to septal nuclei, bed nucleus of the stria terminalis, paraventricular and reuniens nuclei of the thalamus, zona incerta, subthalamic nucleus, central gray, substantia nigra, raphe nuclei, parabrachial area, medullary reticular formation, and nucleus of the solitary tract (Peyron et al. 1998, Xu et al. 2013). This complex connectivity suggests roles for orexin signaling, that is in part, mediated by downstream PKA signaling, in physiologic functions such as sleep, feeding, and addiction as well as in the regulation of neuroendocrine systems.

Crossing the RIIBKO mouse with well-characterized mouse models of obesity such as the $o b / o b$ mouse has helped elucidate the mechanisms by which PKA and other 'obesity' genes function in regulating energy balance (Nolan et al. 2004, Newhall et al. 2005). Double KO of Prkar $2 b$ and $O b$ partially rescued the obese $o b / o b$ phenotype of the leptin-deficient mouse. Body weight and energy intake were significantly decreased, while both night-time locomotor activity and basal oxygen consumption were increased. Deletion of RII $\beta$ activated BAT in the double (RII $\beta / \mathrm{ob}) \mathrm{KO}$ and partially restored the ability to maintain body temperature in sub-thermoneutral conditions (Newhall et al. 2005). Similarly, deletion of NPY in the ob/ob mouse attenuated the obesity and glucose dysregulation of the ob/ob mouse, but did not entirely reverse the ob/ob phenotype (Erickson et al. 1996). Inhibition of NPY by amphetamine has an anorectic effect that increases both PKA and CREB in hypothalamus of rats (Hsieh et al. 2007). These studies reaffirm the importance of PKA RII $\beta$ in hypothalamus and specifically in leptin-responsive cells in neuronal- and AT regulation of energy balance. 
Agouti lethal yellow mice (Ay) express the agouti gene next to a constitutively active promoter causing high expression of the agouti peptide which is a powerful antagonist of both MC3R and MC4R (Bultman et al. 1992, Miller et al. 1993). Ay mice have hyperphagia, hypoactivity, and increased fat mass. Agonism of MC4R directly enhances intracellular hypothalamic cAMP levels through its activation of $\mathrm{G}_{\mathrm{s}}$ that in turn activates PKA to enable normal energy homeostatic control. The MC4R KO mouse was hyperphagic and had a severe obese phenotype (Huszar et al. 1997). PKA RII $\beta$ deletion in the $\mathrm{A}^{\mathrm{y}}$ mouse successfully reversed the obesity of $\mathrm{A}^{\mathrm{y}}$ mice and heterozygosity of RII $\beta$ KO led to partial rescue of the obese phenotype (Czyzyk et al. 2008), confirming the essential regulatory role of RII $\beta$ in the melanocortin system downstream of MC4R in hypothalamus.

Intriguingly, the use of specific Cre drivers to re-express RII $\beta$ in specific neuronal populations of the hypothalamus illustrated that it was not a single population of cells mediating the hyperactive, lean phenotype of the RII $\beta \mathrm{KO}$ mouse. While neuronal re-expression of RII $\beta$ using a Synapsin-Cre transgenic line rescued both the hyperactive and lean phenoytpes, re-expression in striatum via DARPP-32-Cre reversed only the hyperactivity, and AAV-Cre-mediated hypothalamic re-expression rescued the lean phenotype (Zheng et al. 2013).

In medium spiny neurons (MSNs) and hippocampus, PKA RII $\beta$ localizes to dendrites by its association with AKAP5 and mice lacking these associations displayed defects in both synaptic plasticity and operant tasks with a food reward that manifest behaviorally (Weisenhaus et al. 2010). PKA RIa mediates the effects of dopamine in striatal MSNs and is necessary for appropriate MSN cytoplasmic function (Yang et al. 2014). Expression of a dominant negative form of RI $\alpha$ in striatal MSNs in mice caused growth retardation, hypophagia, and impaired locomotor activity.

cAMP/PKA signaling performs numerous functions throughout the CNS and its roles are well-established in the molecular pathways governing fear and fear memory. PKA mouse models have also demonstrated a role for PKA signaling in anxiety. Increased cAMP signaling has been associated with an anxiety phenotype in mice that were haploinsufficient for either Prkar1a (Keil et al. 2012) or Prkaca (Briassoulis et al. 2016). Similarly, in mice overexpressing $\mathrm{G}_{\mathrm{s}} \alpha$, enhanced striatal PKA enzymatic activity was associated with an anxiety phenotype (Favilla et al. 2008). While current data on the relationship between anxiety and obesity is mixed (Gariepy et al. 2010), anxiety disorders are the most prevalent mental disorders in the developed world (Kessler \& Wang 2008). Better understanding the relationship between psychological disorders and behaviors that impact energy balance are key to identifying therapeutic approaches to some forms of obesity.

\section{The role of Prkar2b in thermogenesis and regulation of adiposity}

Studying the RII $\beta \mathrm{KO}$ and Ucp1 KO mouse provided novel mechanistic information about BAT activation and the role of RIIB in the central regulation of energy balance. In a thermoneutral environment, RII $\beta \mathrm{KO}$ mice had four times more UCP1 protein in BAT than WT mice. Double KO of RII $\beta$ and UCP1 in mice, however, resulted in BAT cellularity that more closely resembled that of the Ucp1 KO mouse, confirming that RII $\beta$ disruption affects BAT activity upstream of UCP1 (Nolan et al. 2004) (Fig. 2). The elevated oxygen consumption rate characteristic of the RII $\beta K O$ mouse was dependent on UCP1, yet leanness was conveyed in the double $\mathrm{KO}$ mouse despite small increases in adiposity compared to the single RII $\beta$ mutant. The evidence that enhanced $\beta 3$-adrenergic stimulation and activation of UCP1 was not the primary component of the RII $\beta \mathrm{KO}$ lean phenotype pointed to a non-adipose tissue driver controlling energy balance.

\section{PKA signaling plays a central role in the regulation of AT function}

\section{Lipolysis and non-shivering thermogenesis}

Using mouse models and in vitro cell studies, McKnight and others have demonstrated how PKA activity, and specifically, the subunits RII $\beta$ and RI $\alpha$, can regulate lipolysis through dynamic compensatory mechanisms in the PKA system (Cummings et al. 1996, McKnight et al. 1998, Planas et al. 1999). While multiple PKA subunits including RII $\beta$, RI $\alpha, C \alpha$, and C $\beta 1$ are expressed in adipocytes, under normal conditions the major holoenzyme comprises RII $\beta$ and $\mathrm{C} \alpha$. Studies exploiting the unique binding properties of cAMP analogs that bind specifically to one of the two cAMP-binding sites (site 1, C-8 analogs; site 2; C-6 analogs) have demonstrated that the type II regulatory subunit is responsible for the lipolytic response and that when site-1- and site-2-specific cAMP analogs are incubated in combination, they work synergistically (Beebe et al. 1984).

PKA RII $\beta$ is the most abundant regulatory subunit in AT and its deletion impacts lipolytic activation in both 
BAT (Cummings et al. 1996) and WAT (Planas et al. 1999) via an isoform switch from RII $\beta$ to RI $\alpha$. The net result was increased basal PKA activity and dramatically increased UCP1. Lipolytic stimulation by isoproterenol $(\beta 1, \beta 2$, and $\beta 3$ ) or selective stimulation of $\beta 3$-adrenergic receptors with CL 316,243, however, was severely blunted in RII $\beta$ KO mice despite unchanged PKA-mediated transcriptional regulation in AT (Planas et al. 1999). Interestingly, PKA inhibition of acetyl-CoA carboxylase (ACC), lipoprotein lipase (LPL), and glucose transporter type 4 (GLUT4) (and enhancement of phosphoenolpyruvate carboxykinase (PEPCK) in RII $\beta K O$ mice did not differ from WT mice under both fed and fasted states, despite altered PKA enzymatic activity initiated by the isoform switch. This differential response in AT to $\beta$-adrenergic stimulation further supports the finding that type II PKA activity is responsible for the lipolytic response.

Along a similar line of investigation, constitutive activation of PKA in WAT by expressing an activated C $\alpha$ allele under the adiponectin (Adipoq) promoter in mice increased energy expenditure, AT PKA activity, and UCP1 induction (Dickson et al. 2016). These changes to AT physiology were sufficient to prevent DIO and preserve insulin sensitivity after HFD challenge in mice. In vitro, the stimulation of normal human and mouse adipocytes with forskolin, isoproterenol, or dibutyrl-cAMP caused increased oxidative and glycolytic respiration, and as expected, the increased oxygen consumption rate was dependent on PKA-induced lipolysis (Yehuda-Shnaidman et al. 2010).

PKA regulation of lipolysis downstream of $\beta$-adrenergic receptors ( $\beta$-adr Rs) in AT relies on phosphorylation of several key lipolytic players. Elevated cAMP levels activate PKA that in turn phosphorylates the two primary lipolytic proteins, adipose triglyceride lipase (ATGL) and hormone sensitive lipase (HSL), that account for almost all triglyceride lipase activity in adipocytes (Schweiger et al. 2006). $\beta$-adr $\mathrm{R}$ activation induces the PKA-mediated phosphorylation of ATGL at Ser ${ }^{406}$ (Ser ${ }^{404}$ in humans) to generate a moderate increase in ATGL-mediated lipolysis (Pagnon et al. 2012), and this specific phosphorylation also occurs during fasting or moderate intensity exercise (Haemmerle et al. 2006, Huijsman et al. 2009).

Hormone-sensitive lipase (HSL) is a major phosphorylation target of PKA at three serine residues: Ser ${ }^{563}$, Ser ${ }^{659}$, and Ser ${ }^{660}$ (Stralfors \& Belfrage 1983, Anthonsen et al. 1998). HSL phosphorylation is also regulated by perilipin in a PKA-dependent manner (Brasaemle 2007). Perilipin, a protein that is integral in organizing the interaction of lipolytic proteins on the surface of lipid droplets, is phosphorylated by PKA on Ser ${ }^{492}$ and Ser ${ }^{517}$. This PKA-mediated phosphorylation enables the dissociation of the ATGL coactivator, CGI-58, that can then associate with ATGL on lipid droplets to permit its PKA-dependent activation to enable basal and stimulated lipolysis (Granneman et al. 2009). HSL also relies on the phosphorylation of perilipin-1 at Ser ${ }^{517}$ by PKA to facilitate its access to lipid droplets (Londos et al. 1999, Miyoshi et al. 2007). These phosphorylations by PKA are the hallmark of $\beta$-adr R-stimulated lipolysis that generate free fatty acids for use as fuel by other tissues and maintain healthy nutrient partitioning, lipid storage and utilization, and permit non-shivering thermogenesis (Fig. 2).

\section{Adipogenesis}

Although the mechanism is unknown, adipogenesis requires the availability of intracellular cAMP for the differentiation of 3T3L1 preadipocytes into adipocytes that is concomitant with the programmed expression of the genes that comprise an adipocyte-specific profile which is stimulated by phosphodiesterase inhibitors including IBMX (Spiegelman et al. 1993). More recently, we have seen that IBMX permits CREB phosphorylation through the PKA signaling pathway and upregulates $\mathrm{C} / \mathrm{EBP} \beta$ to stimulate adipogenesis in 3T3-L1 preadipocytes (Zhang et al. 2004, Lee et al. 2018).

\section{Involvement of the PKA pathway in hepatic glucose metabolism and lipid metabolism and storage}

Hepatic PKA signaling in the fasted state initiates gluconeogenesis as a nutrient-sensing response. In obesity, impairment of this system leads to the inappropriate initiation of gluconeogenesis that is a key part of the associated metabolic dysregulation (Fig. 2). Activation of the PKA pathway in hepatocytes increased the gene expression of gluconeogenic gene expression through the de-phosphorylation CREB-regulated transcription coactivator 2 (CRTC2) (Altarejos \& Montminy 2011). It has also been demonstrated that biguanides, the most widely used drug to treat type II diabetes mellitus (T2DM), acts by antagonism of glucagon and the subsequent accumulation of AMP and decrease of cAMP that in turn reduces PKA signaling (Miller et al. 2013). Along a similar line of investigation, metformin was unable to reduce hepatic glucose production or hyperglucagonemia in 
mice that expressed a constitutively active form of PKA (He et al. 2016).

PKA is intimately involved in hepatic fatty acid uptake and trafficking and lipogenesis through the modification of downstream proteins. PKA has been shown to activate CREBH transcriptional activity through the phosphorylation of Ser ${ }^{133}$ in the fasted state (Shaywitz \& Greenberg 1999, Nakagawa \& Shimano 2018). Lee et al. determined that, once activated, CREB H (CREBH) can constrain plasma triglyceride levels to a normal range through the downstream activation of a variety of genes involved in triglyceride metabolism in CREB3L3---mice. KO of CREBH led to downregulation of Fads1, Fads2, Elovl2, Cidec, Apoc2, Apoa5, hepatic Fgf21, Apoa4, Elov5, and G0s2, while overexpression caused significant upregulation of Cidec, Apoc2, Fgf21, and Apoa4 (Lee et al. 2011). PKA is also involved in the regulation of CREBH through the phosphorylation of peroxisome proliferatoractivated receptor alpha (PPAR $\alpha)$ at its DNA-binding domain, resulting in activation of PPAR $\alpha$ that in turn upregulates CREBH by binding to the PPRE region of the CREBH promotor (Nakagawa \& Shimano 2018). PPAR $\alpha$ has further implications in hepatic lipid metabolism through its ability to promote fatty acid $\beta$ oxidation, ketogenesis, and lipid transport. Kersten and others showed that the deletion of PPAR $\alpha$ in mice caused development of fastinginduced hepatic steatosis due to reduced hepatic fatty acid uptake and oxidation, thus linking PKA regulation to proper maintenance of fasting-fatty-acid regulation (Kersten et al. 1999).

PKA is crucial to hepatic lipogenesis through the regulation of sterol regulatory element-binding protein (SREBP), an integral ER membrane protein involved in stress-induced lipogenesis, and carbohydrate regulatory element-binding protein (ChREBP), a glycolytic enzyme involved in stimulating the expression of numerous lipogenic genes (Kawaguchi et al. 2001, Kammoun et al. 2009). PKA can inhibit SREBP both directly and through the activation of farnesoid X receptor (FXR) or sirtuin 1

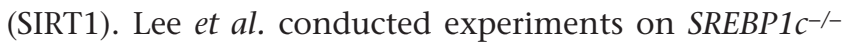
mice that proved PKA directly inhibits SREBP through phosphorylation of its $\mathrm{Ser}^{308}$ residue that promotes its sumoylation and ultimate degradation (Lee et al. 2014). Studies conducted in WT and FXR mutant cells that lack $\mathrm{Ser}^{325}$ and $\mathrm{Ser}^{357}$ but had intact protein function revealed that PKA phosphorylation of FXR at $\operatorname{Ser}^{325}$ and $\operatorname{Ser}^{357}$ was necessary and sufficient to stimulate FXR transcription and protein function in WT cells, as this effect was absent in mutant cells (Ploton et al. 2018). Other studies have suggested that FXR then proceeds to suppress the ability of LXR, a reverse cholesterol transport protein, to stimulate SREBP (Watanabe et al. 2004). In fasting conditions, PKA also activates SIRT1, a NAD+-dependent protein deacetylase, through phosphorylation of $\mathrm{Thr}^{522}$. Once phosphorylated, SIRT1 deacetylated SREBP at Lys ${ }^{289}$ and Lys ${ }^{309}$, suppressing its ability to conduct lipogenesis (Ponugoti et al. 2010, Guo et al. 2012). ChREBP is altered both directly and indirectly by PKA. ChREBP is inhibited through phosphorylation by PKA and activated protein phosphatase 2 (PP2A)-mediated dephosphorylation at Ser ${ }^{196}$ (Kawaguchi et al. 2001).

Mouse models of PKA deficiency have also indirectly implicated PKA in the regulation of hepatic lipid metabolism, in some cases, likely as a secondary effect of DIO resistance. One such model is the RII $\beta$ KO mouse, that had enhanced lipolysis (Cummings et al. 1996), maintained superior glucose sensitivity after chronic HFD, and had significantly decreased hepatic lipid accumulation compared to WT littermates (Cummings et al. 1996, Planas et al. 1999). The C $\beta K O$ mouse similarly resisted DIO, glucose intolerance, and insulin insensitivity as well as excessive hepatic lipid accumulation after exposure to HFD feeding (Enns et al. 2009, London et al. 2019). These various defects in PKA signaling all had the similar end point of altered nutrient partitioning and a decrease in the hepatic lipid accumulation that is a common feature of obesity. A third knockout mouse model of RII $\alpha$ deficiency had reduced hepatic steatosis after chronic HFD due to, in part, decreased hepatic PKA activity that occurred only after the challenge of over-nutrition, suggesting the ability of the PKA system to respond to changes in nutritional status (London et al. 2014a).

\section{Regulation of insulin secretion in pancreatic $\beta$ cells}

Pancreatic PKA dysfunction links obesity to the impairment of glucose-stimulated insulin secretion. Proper functioning of the cAMP signaling pathway in pancreatic $\beta$-cells is necessary for glucose-stimulated insulin secretion, one of the first processes disrupted in the development of T2DM (Gerich 2002, Nolan et al. 2011) (Fig. 2). In T2DM, impaired glucose-stimulated insulin secretion can be ameliorated by the incretin, glucagon-like peptide-1 (GLP-1) (Egan et al. 2002). GLP-1 enhances insulin secretion in part by cAMPstimulated PKA-dependent phosphorylation of snapin, a component of a larger complex that mediates insulin exocytosis from pancreatic $\beta$ cells (Song et al. 2011). 
PKA directly phosphorylates CREB and de-phosphorylates cAMP-regulated transcriptional coactivators (CRTCs) to promote cellular gene expression. CREB phosphorylation upregulates insulin receptor substrate 2 (IRS2) in $\beta$ cells and promotes proper islet function. Expression of a dominant-negative from of A-CREB that blocks all family members (CREB1, ATF1, and CREM) led to hyperglycemia (Jhala et al. 2003). In the state of hyperglycemia, protein kinase A inhibitor $\beta$ is induced in $\beta$ cells to inhibit the PKA signaling pathway upstream of CREB and CRTC2 (Blanchet et al. 2015). Insulin resistance causes disruption of $\beta$ cell CREB activity via a decrease in expression of the transcription factor MafA that can be attenuated by disruption of the PKIB gene.

\section{Conclusions}

The PKA system exerts tight control over the regulation of metabolism and energy balance in many organ systems through an impressive network of GPCR ligands and downstream phosphorylation targets, including CREB which regulates transcription of CRE-containing genes. Studies in mice and cell systems have illuminated many of the mechanisms that govern WAT lipolysis, BAT activation, and the central regulation of both, the modulation of leptin sensitivity in hypothalamus, specifically through the subunit RII $\beta$, and hypothalamic regulation of the melanocortin system. With respect to a role for PKA in glucose metabolism and the development of T2DM, mouse and cell studies have illuminated the details of PKA function in pancreatic $\beta$-cell insulin secretion as well as facets of hepatic glucose and lipid metabolism regulation. While human studies are few, we have seen differences in the PKA system between lean and obese individuals and identified PKA signaling genes that can cause dysregulation of the HPA axis in CS. While there is a growing body of evidence that demonstrates the translation of this basic research in humans, the exploration of potential therapeutics, including specific small molecule agonists and inhibitors of the PKA systems, is nascent.

Transgenic and KO mouse models enabled the manipulation of genes with central roles in energy homeostasis that improved our understanding of this complex system of integrated central and peripheral controls. However, the $o b / o b$ mouse is an example of a break in the chain of translation of obesity research from mouse to human. While leptin replacement in the $o b / o b$ mouse was effective in rescuing the obesity of the $o b / o b$ mouse and generated hope for a possible therapeutic for human obesity, leptin replacement was not a viable 'cure' for obesity, in part, because of developed leptin resistance. Similarly, the prospect of enhancing BAT activation and browning of WAT depots has become a popular line of research for its potential therapeutic value in humans. While it is likely that constitutive activation of PKA in AT can prevent DIO in mice, WAT and BAT activation in humans is not likely to be a viable preventive therapeutic for DIO, in part, because of species-specific physiologic differences such as the dramatic differences in body surface area. Despite the potential incongruities, the body of work in mouse models described here have enriched our knowledge of how the PKA-regulated systems are integrated to govern whole body energy homeostasis and maintain proper nutrient sensing and glucose metabolism.

\section{Declaration of interest}

Dr Stratakis holds patents on the PRKAR1A, PDE11A, and GPR101 genes and/or their function and has received research funding from Pfizer Inc. on the genetics and treatment of abnormalities of growth hormone secretion. The other authors have nothing to disclose.

\section{Funding}

This work was funded by the Eunice Kennedy Shriver National Institute of Child Health Intramural Research Program.

\section{Acknowledgements}

The authors would like to thank Nichole C Swan from the Eunice Kennedy Shriver National Institute of Child Health and Human Development Computer Support Services Core for her work on the graphics used in the figures.

\section{References}

Adams SR, Harootunian AT, Buechler YJ, Taylor SS \& Tsien RY 1991 Fluorescence ratio imaging of cyclic AMP in single cells. Nature 349 694-697. (https://doi.org/10.1038/349694a0)

Altarejos JY \& Montminy M 2011 CREB and the CRTC co-activators: sensors for hormonal and metabolic signals. Nature Reviews: Molecular Cell Biology 12 141-151. (https://doi.org/10.1038/nrm3072)

Amieux PS \& McKnight GS 2002 The essential role of RI alpha in the maintenance of regulated PKA activity. Annals of the New York Academy of Sciences 968 75-95. (https://doi. org/10.1111/j.1749-6632.2002.tb04328.x)

Amieux PS, Cummings DE, Motamed K, Brandon EP, Wailes LA, Le K, Idzerda RL \& McKnight GS 1997 Compensatory regulation of RIalpha protein levels in protein kinase A mutant mice. Journal of Biological Chemistry 272 3993-3998. (https://doi.org/10.1074/jbc.272.7.3993)

Amieux PS, Howe DG, Knickerbocker H, Lee DC, Su T, Laszlo GS, Idzerda RL \& McKnight GS 2002 Increased basal cAMP-dependent 
protein kinase activity inhibits the formation of mesodermderived structures in the developing mouse embryo. Journal of Biological Chemistry 277 27294-27304. (https://doi.org/10.1074/jbc. M200302200)

Anthonsen MW, Ronnstrand L, Wernstedt C, Degerman E \& Holm C 1998 Identification of novel phosphorylation sites in hormonesensitive lipase that are phosphorylated in response to isoproterenol and govern activation properties in vitro. Journal of Biological Chemistry 273 215-221. (https://doi.org/10.1074/jbc.273.1.215)

Bartness TJ, Liu Y, Shrestha YB \& Ryu V 2014 Neural innervation of white adipose tissue and the control of lipolysis. Frontiers in Neuroendocrinology 35 473-493. (https://doi.org/10.1016/j. yfrne.2014.04.001)

Beebe SJ, Holloway R, Rannels SR \& Corbin JD 1984 Two classes of cAMP analogs which are selective for the two different cAMP-binding sites of type II protein kinase demonstrate synergism when added together to intact adipocytes. Journal of Biological Chemistry 259 3539-3547.

Beuschlein F, Fassnacht M, Assie G, Calebiro D, Stratakis CA, Osswald A, Ronchi CL, Wieland T, Sbiera S, Faucz FR, et al. 2014 Constitutive activation of PKA catalytic subunit in adrenal Cushing's syndrome. New England Journal of Medicine 370 1019-1028. (https://doi. org/10.1056/NEJMoa1310359)

Blanchet E, Van De Velde S, Matsumura S, Hao E, Lelay J, Kaestner K \& Montminy M 2015 Feedback inhibition of CREB signaling promotes beta cell dysfunction in insulin resistance. Cell Reports 10 1149-1157. (https://doi.org/10.1016/j.celrep.2015.01.046)

Brandon EP, Gerhold KA, Qi M, McKnight GS \& Idzerda RL 1995 Derivation of novel embryonic stem cell lines and targeting of cyclic AMP-dependent protein kinase genes. Recent Progress in Hormone Research 50 403-408. (https://doi.org/10.1016/b978-0-12-5711500.50028-7)

Brasaemle DL 2007 Thematic review series: adipocyte biology. The perilipin family of structural lipid droplet proteins: stabilization of lipid droplets and control of lipolysis. Journal of Lipid Research 48 2547-2559. (https://doi.org/10.1194/jlr.R700014-JLR200)

Bray GA 1992 Genetic, hypothalamic and endocrine features of clinical and experimental obesity. Progress in Brain Research 93 333-340; discussion 340-341. (https://doi.org/10.1016/s0079-6123(08)64583-5)

Briassoulis G, Keil MF, Naved B, Liu S, Starost MF, Nesterova M, Gokarn N, Batistatos A, Wu TJ \& Stratakis CA 2016 Studies of mice with cyclic AMP-dependent protein kinase (PKA) defects reveal the critical role of PKA's catalytic subunits in anxiety. Behavioural Brain Research 307 1-10. (https://doi.org/10.1016/j.bbr.2016.03.001)

Brownell KD \& Wadden TA 1992 Etiology and treatment of obesity: understanding a serious, prevalent, and refractory disorder. Journal of Consulting and Clinical Psychology 60 505-517. (https://doi. org/10.1037//0022-006x.60.4.505)

Bultman SJ, Michaud EJ \& Woychik RP 1992 Molecular characterization of the mouse agouti locus. Cell 71 1195-1204. (https://doi. org/10.1016/s0092-8674(05)80067-4)

Burton KA, Johnson BD, Hausken ZE, Westenbroek RE, Idzerda RL, Scheuer T, Scott JD, Catterall WA \& McKnight GS 1997 Type II regulatory subunits are not required for the anchoring-dependent modulation of $\mathrm{Ca} 2+$ channel activity by cAMP-dependent protein kinase. PNAS 94 11067-11072. (https://doi.org/10.1073/ pnas.94.20.11067)

Cadd G \& McKnight GS 1989 Distinct patterns of cAMP-dependent protein kinase gene expression in mouse brain. Neuron 3 71-79. (https://doi.org/10.1016/0896-6273(89)90116-5)

Corbin JD \& Keely SL 1977 Characterization and regulation of heart adenosine $3^{\prime}: 5^{\prime}$-monophosphate-dependent protein kinase isozymes. Journal of Biological Chemistry 252 910-918.

Corbin JD, Keely SL \& Park CR 1975 The distribution and dissociation of cyclic adenosine $3^{\prime}: 5^{\prime}$-monophosphate-dependent protein kinases in adipose, cardiac, and other tissues. Journal of Biological Chemistry $\mathbf{2 5 0}$ 218-225.
Cummings DE, Brandon EP, Planas JV, Motamed K, Idzerda RL \& McKnight GS 1996 Genetically lean mice result from targeted disruption of the RII beta subunit of protein kinase A. Nature 382 622-626. (https://doi.org/10.1038/382622a0)

Czyzyk TA, Sikorski MA, Yang L \& McKnight GS 2008 Disruption of the RIIbeta subunit of PKA reverses the obesity syndrome of Agouti lethal yellow mice. PNAS 105 276-281. (https://doi.org/10.1073/ pnas.0710607105)

Desseyn JL, Burton KA \& McKnight GS 2000 Expression of a nonmyristylated variant of the catalytic subunit of protein kinase A during male germ-cell development. PNAS 97 6433-6438. (https:// doi.org/10.1073/pnas.97.12.6433)

Dickson LM, Gandhi S, Layden BT, Cohen RN \& Wicksteed B 2016 Protein kinase A induces UCP1 expression in specific adipose depots to increase energy expenditure and improve metabolic health. American Journal of Physiology: Regulatory, Integrative and Comparative Physiology 311 R79-R88. (https://doi.org/10.1152/ ajpregu.00114.2016)

Ding L, Zhang F, Zhao MX, Ren XS, Chen Q, Li YH, Kang YM \& Zhu GQ 2016 Reduced lipolysis response to adipose afferent reflex involved in impaired activation of adrenoceptor-cAMP-PKA-hormone sensitive lipase pathway in obesity. Scientific Reports 6 34374. (https://doi. org/10.1038/srep34374)

Egan JM, Clocquet AR \& Elahi D 2002 The insulinotropic effect of acute exendin- 4 administered to humans: comparison of nondiabetic state to type 2 diabetes. Journal of Clinical Endocrinology and Metabolism $\mathbf{8 7}$ 1282-1290. (https://doi.org/10.1210/jcem.87.3.8337)

Elias CF, Aschkenasi C, Lee C, Kelly J, Ahima RS, Bjorbaek C, Flier JS, Saper CB \& Elmquist JK 1999 Leptin differentially regulates NPY and POMC neurons projecting to the lateral hypothalamic area. Neuron 23 775-786. (https://doi.org/10.1016/s0896-6273(01)80035-0)

Elmquist JK, Elias CF \& Saper CB 1999 From lesions to leptin: hypothalamic control of food intake and body weight. Neuron 22 221-232. (https://doi.org/10.1016/s0896-6273(00)81084-3)

Enns LC, Morton JF, Mangalindan RS, McKnight GS, Schwartz MW, Kaeberlein MR, Kennedy BK, Rabinovitch PS \& Ladiges WC 2009 Attenuation of age-related metabolic dysfunction in mice with a targeted disruption of the Cbeta subunit of protein kinase A. Journals of Gerontology: Series A, Biological Sciences and Medical Sciences 64 1221-1231. (https://doi.org/10.1093/gerona/glp133)

Erickson JC, Hollopeter G \& Palmiter RD 1996 Attenuation of the obesity syndrome of ob/ob mice by the loss of neuropeptide Y. Science $\mathbf{2 7 4}$ 1704-1707. (https://doi.org/10.1126/science.274.5293.1704)

Espiard S, Ragazzon B \& Bertherat J 2014 Protein kinase A alterations in adrenocortical tumors. Hormone and Metabolic Research 46 869-875. (https://doi.org/10.1055/s-0034-1385908)

Favilla C, Abel T \& Kelly MP 2008 Chronic Galphas signaling in the striatum increases anxiety-related behaviors independent of developmental effects. Journal of Neuroscience 28 13952-13956. (https://doi.org/10.1523/JNEUROSCI.4986-08.2008)

Feliciello A, Gottesman ME \& Avvedimento EV 2001 The biological functions of A-kinase anchor proteins. Journal of Molecular Biology $\mathbf{3 0 8}$ 99-114. (https://doi.org/10.1006/jmbi.2001.4585)

Flores-Opazo M, Trieu J, Naim T, Valladares-Ide D, Zbinden-Foncea H \& Stapleton D 2019 Defective fasting-induced PKA activation impairs adipose tissue glycogen degradation in obese Zucker rats. International Journal of Obesity $\mathbf{4 4} 500-509$.

Gariepy G, Nitka D \& Schmitz N 2010 The association between obesity and anxiety disorders in the population: a systematic review and meta-analysis. International Journal of Obesity 34 407-419. (https://doi. org/10.1038/ijo.2009.252)

Garrel G, Delahaye R, Hemmings BA \& Counis R 1995 Modulation of regulatory and catalytic subunit levels of cAMP-dependent protein kinase $\mathrm{A}$ in anterior pituitary cells in response to direct activation of protein kinases A and C or after GnRH stimulation. Neuroendocrinology 62 514-522. (https://doi.org/10.1159/000127042) https://joe.bioscientifica.com

https://doi.org/10.1530/JOE-20-0035
(C) 2020 Society for Endocrinology Published by Bioscientifica Ltd. Printed in Great Britain 
Gerich JE 2002 Is reduced first-phase insulin release the earliest detectable abnormality in individuals destined to develop type 2 diabetes? Diabetes 51 (Supplement 1) S117-S121. (https://doi.org/10.2337/ diabetes.51.2007.s117)

Gonzalez GA \& Montminy MR 1989 Cyclic AMP stimulates somatostatin gene transcription by phosphorylation of CREB at serine 133. Cell $\mathbf{5 9}$ 675-680. (https://doi.org/10.1016/0092-8674(89)90013-5)

Granneman JG, Moore HP, Krishnamoorthy R \& Rathod M 2009 Perilipin controls lipolysis by regulating the interactions of $\mathrm{AB}$-hydrolase containing 5 (Abhd5) and adipose triglyceride lipase (Atgl). Journal of Biological Chemistry 284 34538-34544. (https://doi.org/10.1074/jbc. M109.068478)

Groussin L, Kirschner LS, Vincent-Dejean C, Perlemoine K, Jullian E, Delemer B, Zacharieva S, Pignatelli D, Carney JA, Luton JP, et al. 2002 Molecular analysis of the cyclic AMP-dependent protein kinase A (PKA) regulatory subunit 1A (PRKAR1A) gene in patients with Carney complex and primary pigmented nodular adrenocortical disease (PPNAD) reveals novel mutations and clues for pathophysiology: augmented PKA signaling is associated with adrenal tumorigenesis in PPNAD. American Journal of Human Genetics 71 1433-1442. (https:// doi.org/10.1086/344579)

Guo X, Kesimer M, Tolun G, Zheng X, Xu Q, Lu J, Sheehan JK, Griffith JD \& Li X 2012 The NAD(+)-dependent protein deacetylase activity of SIRT1 is regulated by its oligomeric status. Scientific Reports $\mathbf{2} 640$. (https://doi.org/10.1038/srep00640)

Guthrie CR, Skalhegg BS \& McKnight GS 1997 Two novel brain-specific splice variants of the murine Cbeta gene of cAMP-dependent protein kinase. Journal of Biological Chemistry 272 29560-29565. (https://doi. org/10.1074/jbc.272.47.29560)

Haemmerle G, Lass A, Zimmermann R, Gorkiewicz G, Meyer C, Rozman J, Heldmaier G, Maier R, Theussl C, Eder S, et al. 2006 Defective lipolysis and altered energy metabolism in mice lacking adipose triglyceride lipase. Science $\mathbf{3 1 2}$ 734-737. (https://doi. org/10.1126/science.1123965)

Hara J, Beuckmann CT, Nambu T, Willie JT, Chemelli RM, Sinton CM, Sugiyama F, Yagami K, Goto K, Yanagisawa M, et al. 2001 Genetic ablation of orexin neurons in mice results in narcolepsy, hypophagia, and obesity. Neuron 30 345-354. (https://doi.org/10.1016/s08966273(01)00293-8)

He L, Chang E, Peng J, An H, McMillin SM, Radovick S, Stratakis CA \& Wondisford FE 2016 Activation of the cAMP-PKA pathway antagonizes metformin suppression of hepatic glucose production. Journal of Biological Chemistry 291 10562-10570. (https://doi. org/10.1074/jbc.M116.719666)

Heller WT, Vigil D, Brown S, Blumenthal DK, Taylor SS \& Trewhella J 2004 C subunits binding to the protein kinase A RI alpha dimer induce a large conformational change. Journal of Biological Chemistry 279 19084-19090. (https://doi.org/10.1074/jbc.M313405200)

Horvath A, Giatzakis C, Tsang K, Greene E, Osorio P, Boikos S, Libe R, Patronas Y, Robinson-White A, Remmers E, et al. 2008a A cAMPspecific phosphodiesterase (PDE8B) that is mutated in adrenal hyperplasia is expressed widely in human and mouse tissues: a novel PDE8B isoform in human adrenal cortex. European Journal of Human Genetics 16 1245-1253. (https://doi.org/10.1038/ejhg.2008.85)

Horvath A, Mericq V \& Stratakis CA 2008b Mutation in PDE8B, a cyclic AMP-specific phosphodiesterase in adrenal hyperplasia. New England Journal of Medicine 358 750-752. (https://doi.org/10.1056/ NEJMc0706182)

Howe DG, Wiley JC \& McKnight GS 2002 Molecular and behavioral effects of a null mutation in all PKA C beta isoforms. Molecular and Cellular Neurosciences 20 515-524. (https://doi.org/10.1006/mcne.2002.1119)

Hsieh YS, Yang SF \& Kuo DY 2007 Intracerebral administration of protein kinase A or cAMP response element-binding protein antisense oligonucleotide can modulate amphetamine-mediated appetite suppression in free-moving rats. American Journal of
Physiology: Endocrinology and Metabolism 292 E123-E131. (https://doi. org/10.1152/ajpendo.00195.2006)

Huang Y, Roelink H \& McKnight GS 2002 Protein kinase A deficiency causes axially localized neural tube defects in mice. Journal of Biological Chemistry 277 19889-19896.

Huijsman E, Van De Par C, Economou C, Van Der Poel C, Lynch GS, Schoiswohl G, Haemmerle G, Zechner R \& Watt MJ 2009 Adipose triacylglycerol lipase deletion alters whole body energy metabolism and impairs exercise performance in mice. American Journal of Physiology: Endocrinology and Metabolism 297 E505-E513. (https://doi. org/10.1152/ajpendo.00190.2009)

Huszar D, Lynch CA, Fairchild-Huntress V, Dunmore JH, Fang Q, Berkemeier LR, Gu W, Kesterson RA, Boston BA, Cone RD, et al. 1997 Targeted disruption of the melanocortin- 4 receptor results in obesity in mice. Cell 88 131-141. (https://doi.org/10.1016/s00928674(00)81865-6)

Jhala US, Canettieri G, Screaton RA, Kulkarni RN, Krajewski S, Reed J, Walker J, Lin X, White M \& Montminy M 2003 cAMP promotes pancreatic beta-cell survival via CREB-mediated induction of IRS2. Genes and Development 17 1575-1580. (https://doi.org/10.1101/ gad.1097103)

Jocken JW, Roepstorff C, Goossens GH, Van Der Baan P, Van Baak M, Saris WH, Kiens B \& Blaak EE 2008 Hormone-sensitive lipase serine phosphorylation and glycerol exchange across skeletal muscle in lean and obese subjects: effect of beta-adrenergic stimulation. Diabetes $\mathbf{5 7}$ 1834-1841. (https://doi.org/10.2337/db07-0857)

Kammoun HL, Chabanon H, Hainault I, Luquet S, Magnan C, Koike T, Ferre P \& Foufelle F 2009 GRP78 expression inhibits insulin and ER stress-induced SREBP-1c activation and reduces hepatic steatosis in mice. Journal of Clinical Investigation 119 1201-1215. (https://doi. org/10.1172/JCI37007)

Kawaguchi T, Takenoshita M, Kabashima T \& Uyeda K 2001 Glucose and cAMP regulate the L-type pyruvate kinase gene by phosphorylation/ dephosphorylation of the carbohydrate response element binding protein. PNAS 98 13710-13715. (https://doi.org/10.1073/ pnas.231370798)

Keil MF, Briassoulis G, Gokarn N, Nesterova M, Wu TJ \& Stratakis CA 2012 Anxiety phenotype in mice that overexpress protein kinase A. Psychoneuroendocrinology 37 836-843. (https://doi.org/10.1016/j. psyneuen.2011.09.016)

Kersten S, Seydoux J, Peters JM, Gonzalez FJ, Desvergne B \& Wahli W 1999 Peroxisome proliferator-activated receptor alpha mediates the adaptive response to fasting. Journal of Clinical Investigation 103 1489-1498. (https://doi.org/10.1172/JCI6223)

Kessler RC \& Wang PS 2008 The descriptive epidemiology of commonly occurring mental disorders in the United States. Annual Review of Public Health 29 115-129. (https://doi.org/10.1146/annurev. publhealth.29.020907.090847)

Kim CS, Lee SH, Kim RY, Kim BJ, Li SZ, Lee IH, Lee EJ, Lim SK, Bae YS, Lee $\mathrm{W}$, et al. 2002 Identification of domains directing specificity of coupling to G-proteins for the melanocortin MC3 and MC4 receptors. Journal of Biological Chemistry 277 31310-31317. (https://doi. org/10.1074/jbc.M112085200)

Kim KS, Seeley RJ \& Sandoval DA 2018 Signalling from the periphery to the brain that regulates energy homeostasis. Nature Reviews: Neuroscience 19 185-196. (https://doi.org/10.1038/nrn.2018.8)

Kirschner LS, Carney JA, Pack SD, Taymans SE, Giatzakis C, Cho YS, Cho-Chung YS \& Stratakis CA 2000 Mutations of the gene encoding the protein kinase A type I-alpha regulatory subunit in patients with the Carney complex. Nature Genetics 26 89-92. (https://doi. org/10.1038/79238)

Kirschner LS, Kusewitt DF, Matyakhina L, Towns WH 2nd, Carney JA, Westphal H \& Stratakis CA 2005 Mouse model for the Carney complex tumor syndrome develops neoplasia in cyclic AMPresponsive tissues. Cancer Research 65 4506-4514. https://joe.bioscientifica.com

https://doi.org/10.1530/JOE-20-0035 (c) 2020 Society for Endocrinology Published by Bioscientifica Ltd. Printed in Great Britain 
Krebs EG 1972 Protein kinases. Current Topics in Cellular Regulation 5 99-133. (https://doi.org/10.1016/B978-0-12-152805-8.50010-1)

Lee JH, Giannikopoulos P, Duncan SA, Wang J, Johansen CT, Brown JD, Plutzky J, Hegele RA, Glimcher LH \& Lee AH 2011 The transcription factor cyclic AMP-responsive element-binding protein $\mathrm{H}$ regulates triglyceride metabolism. Nature Medicine 17 812-815. (https://doi. org/10.1038/nm.2347)

Lee GY, Jang H, Lee JH, Huh JY, Choi S, Chung J \& Kim JB 2014 PIASymediated sumoylation of SREBP1c regulates hepatic lipid metabolism upon fasting signaling. Molecular and Cellular Biology 34 926-938. (https://doi.org/10.1128/MCB.01166-13)

Lee HL, Qadir AS, Park HJ, Chung E, Lee YS, Woo KM, Ryoo HM, Kim HJ \& Baek JH 2018 cAMP/protein kinase A signaling inhibits Dlx 5 expression via activation of CREB and subsequent C/EBPbeta induction in 3T3-L1 preadipocytes. International Journal of Molecular Sciences 19 3161. (https://doi.org/10.3390/ijms19103161)

Lodish M \& Stratakis CA 2016 A genetic and molecular update on adrenocortical causes of Cushing syndrome. Nature Reviews: Endocrinology 12 255-262. (https://doi.org/10.1038/nrendo.2016.24)

London E, Nesterova M, Sinaii N, Szarek E, Chanturiya T, Mastroyannis SA, Gavrilova O \& Stratakis CA 2014a Differentially regulated protein kinase $\mathrm{A}(\mathrm{PKA})$ activity in adipose tissue and liver is associated with resistance to diet-induced obesity and glucose intolerance in mice that lack PKA regulatory subunit type IIalpha. Endocrinology 155 3397-3408. (https://doi.org/10.1210/en.2014-1122)

London E, Rothenbuhler A, Lodish M, Gourgari E, Keil M, Lyssikatos C, De La Luz Sierra M, Patronas N, Nesterova M \& Stratakis CA 2014b Differences in adiposity in Cushing syndrome caused by PRKAR1A mutations: clues for the role of cyclic AMP signaling in obesity and diagnostic implications. Journal of Clinical Endocrinology and Metabolism 99 E303-E310. (https://doi.org/10.1210/jc.2013-1956)

London E, Nesterova M \& Stratakis CA 2017 Acute vs chronic exposure to high fat diet leads to distinct regulation of PKA. Journal of Molecular Endocrinology 59 1-12. (https://doi.org/10.1530/JME-16-0188)

London E, Noguchi A, Springer D, Faidas M, Gavrilova O, Eisenhofer G \& Stratakis CA 2019 The catalytic subunit beta of PKA affects energy balance and catecholaminergic activity. Journal of the Endocrine Society 3 1062-1078. (https://doi.org/10.1210/js.2019-00029)

Londos C, Brasaemle DL, Schultz CJ, Adler-Wailes DC, Levin DM, Kimmel AR \& Rondinone CM 1999 On the control of lipolysis in adipocytes. Annals of the New York Academy of Sciences 892 155-168. (https://doi.org/10.1111/j.1749-6632.1999.tb07794.x)

Mantovani G, Bondioni S, Alberti L, Gilardini L, Invitti C, Corbetta S, Zappa MA, Ferrero S, Lania AG, Bosari S, et al. 2009 Protein kinase A regulatory subunits in human adipose tissue: decreased R2B expression and activity in adipocytes from obese subjects. Diabetes $\mathbf{5 8}$ 620-626. (https://doi.org/10.2337/db08-0585)

Marrades MP, Gonzalez-Muniesa P, Martinez JA \& Moreno-Aliaga MJ 2010 A dysregulation in CES1, APOE and other lipid metabolism-related genes is associated to cardiovascular risk factors linked to obesity. Obesity Facts 3 312-318. (https://doi.org/10.1159/000321451)

McKnight GS, Cadd GG, Clegg CH, Otten AD \& Correll LA 1988 Expression of wild-type and mutant subunits of the cAMP-dependent protein kinase. Cold Spring Harbor Symposia on Quantitative Biology 53 111-119. (https://doi.org/10.1101/sqb.1988.053.01.017)

McKnight GS, Cummings DE, Amieux PS, Sikorski MA, Brandon EP Planas JV, Motamed K \& Idzerda RL 1998 Cyclic AMP, PKA, and the physiological regulation of adiposity. Recent Progress in Hormone Research 53 139-159; discussion 160-161.

Miller MW, Duhl DM, Vrieling H, Cordes SP, Ollmann MM, Winkes BM \& Barsh GS 1993 Cloning of the mouse agouti gene predicts a secreted protein ubiquitously expressed in mice carrying the lethal yellow mutation. Genes and Development 7 454-467. (https://doi.org/10.1101/ gad.7.3.454)

Miller RA, Chu Q, Xie J, Foretz M, Viollet B \& Birnbaum MJ 2013 Biguanides suppress hepatic glucagon signalling by decreasing production of cyclic AMP. Nature 494 256-260. (https://doi. org/10.1038/nature11808)

Miyoshi H, Perfield 2nd JW, Souza SC, Shen WJ, Zhang HH, Stancheva ZS, Kraemer FB, Obin MS \& Greenberg AS 2007 Control of adipose triglyceride lipase action by serine 517 of perilipin A globally regulates protein kinase A-stimulated lipolysis in adipocytes. Journal of Biological Chemistry 282 996-1002. (https://doi.org/10.1074/jbc. M605770200)

Moreno CL, Yang L, Dacks PA, Isoda F, Deursen JM \& Mobbs CV 2016 Role of hypothalamic CREB-binding protein in obesity and molecular reprogramming of metabolic substrates. PLOS ONE 11 e0166381. (https://doi.org/10.1371/journal.pone.0166381)

Nakagawa Y \& Shimano H 2018 CREBH regulates systemic glucose and lipid metabolism. International Journal of Molecular Sciences 191396. (https://doi.org/10.3390/ijms19051396)

Newhall KJ, Cummings DE, Nolan MA \& McKnight GS 2005 Deletion of the RIIbeta-subunit of protein kinase A decreases body weight and increases energy expenditure in the obese, leptin-deficient ob/ob mouse. Molecular Endocrinology 19 982-991. (https://doi.org/10.1210/ me.2004-0343)

Nolan MA, Sikorski MA \& McKnight GS 2004 The role of uncoupling protein 1 in the metabolism and adiposity of RII beta-protein kinase A-deficient mice. Molecular Endocrinology 18 2302-2311. (https://doi. org/10.1210/me.2004-0194)

Nolan CJ, Damm P \& Prentki M 2011 Type 2 diabetes across generations: from pathophysiology to prevention and management. Lancet 378 169-181. (https://doi.org/10.1016/S01406736(11)60614-4)

Otten AD, Parenteau LA, Doskeland S \& McKnight GS 1991 Hormonal activation of gene transcription in ras-transformed NIH3T3 cells overexpressing RII alpha and RII beta subunits of the cAMPdependent protein kinase. Journal of Biological Chemistry $\mathbf{2 6 6}$ 23074-23082.

Pagnon J, Matzaris M, Stark R, Meex RC, Macaulay SL, Brown W, O'brien PE, Tiganis T \& Watt MJ 2012 Identification and functional characterization of protein kinase A phosphorylation sites in the major lipolytic protein, adipose triglyceride lipase. Endocrinology 153 4278-4289. (https://doi.org/10.1210/en.2012-1127)

Peyron C, Tighe DK, Van Den Pol AN, De Lecea L, Heller HC, Sutcliffe JG \& Kilduff TS 1998 Neurons containing hypocretin (orexin) project to multiple neuronal systems. Journal of Neuroscience 18 9996-10015. (https://doi.org/10.1523/ JNEUROSCI.18-23-09996.1998)

Planas JV, Cummings DE, Idzerda RL \& McKnight GS 1999 Mutation of the RIIbeta subunit of protein kinase A differentially affects lipolysis but not gene induction in white adipose tissue. Journal of Biological Chemistry 274 36281-36287. (https://doi.org/10.1074/ jbc.274.51.36281)

Ploton M, Mazuy C, Gheeraert C, Dubois V, Berthier A, DuboisChevalier J, Marechal X, Bantubungi K, Diemer H, Cianferani S, et al. 2018 The nuclear bile acid receptor FXR is a PKA- and FOXA2-sensitive activator of fasting hepatic gluconeogenesis. Journal of Hepatology 69 1099-1109. (https://doi.org/10.1016/j. jhep.2018.06.022)

Ponugoti B, Kim DH, Xiao Z, Smith Z, Miao J, Zang M, Wu SY, Chiang CM, Veenstra TD \& Kemper JK 2010 SIRT1 deacetylates and inhibits SREBP-1C activity in regulation of hepatic lipid metabolism. Journal of Biological Chemistry 285 33959-33970. (https://doi. org/10.1074/jbc.M110.122978)

Qi M, Zhuo M, Skålhegg BS, Brandon EP, Kandel ER, McKnight GS \& Idzerda RL 1996 Impaired hippocampal plasticity in mice lacking the Cbeta1 catalytic subunit of cAMP-dependent protein kinase. PNAS 93 1571-1576.

Schreyer SA, Cummings DE, McKnight GS \& LeBoeuf RC 2001 Mutation of the RIIbeta subunit of protein kinase A prevents diet-induced insulin resistance and dyslipidemia in mice. Diabetes 50 2555-2562. https://joe.bioscientifica.com https://doi.org/10.1530/JOE-20-0035 (c) 2020 Society for Endocrinology Published by Bioscientifica Ltd. Printed in Great Britain 
Schwartz MW, Woods SC, Porte D, Seeley RJ \& Baskin DG 2000 Central nervous system control of food intake. Nature $\mathbf{4 0 4} 661-671$. (https:// doi.org/10.1038/35007534)

Schweiger M, Schreiber R, Haemmerle G, Lass A, Fledelius C, Jacobsen P, Tornqvist H, Zechner R \& Zimmermann R 2006 Adipose triglyceride lipase and hormone-sensitive lipase are the major enzymes in adipose tissue triacylglycerol catabolism. Journal of Biological Chemistry 281 40236-40241. (https://doi.org/10.1074/jbc.M608048200)

Shaywitz AJ \& Greenberg ME 1999 CREB: a stimulus-induced transcription factor activated by a diverse array of extracellular signals. Annual Review of Biochemistry 68 821-861. (https://doi. org/10.1146/annurev.biochem.68.1.821)

Shinyama H, Masuzaki H, Fang H \& Flier JS 2003 Regulation of melanocortin-4 receptor signaling: agonist-mediated desensitization and internalization. Endocrinology 144 1301-1314. (https://doi. org/10.1210/en.2002-220931)

Skalhegg BS, Huang Y, Su T, Idzerda RL, McKnight GS \& Burton KA 2002 Mutation of the Calpha subunit of PKA leads to growth retardation and sperm dysfunction. Molecular Endocrinology 16 630-639. (https:// doi.org/10.1210/mend.16.3.0793)

Song WJ, Seshadri M, Ashraf U, Mdluli T, Mondal P, Keil M, Azevedo M, Kirschner LS, Stratakis CA \& Hussain MA 2011 Snapin mediates incretin action and augments glucose-dependent insulin secretion. Cell Metabolism 13 308-319. (https://doi.org/10.1016/j. cmet.2011.02.002)

Spiegelman BM, Choy L, Hotamisligil GS, Graves RA \& Tontonoz P 1993 Regulation of adipocyte gene expression in differentiation and syndromes of obesity/diabetes. Journal of Biological Chemistry 268 6823-6826.

Stralfors P \& Belfrage P 1983 Phosphorylation of hormone-sensitive lipase by cyclic AMP-dependent protein kinase. Journal of Biological Chemistry 258 15146-15152.

Stratakis CA 2008 Cushing syndrome caused by adrenocortical tumors and hyperplasias (corticotropin-independent Cushing syndrome). Endocrine Development 13 117-132. (https://doi. org/10.1159/000134829)

Tsuneki H, Murata S, Anzawa Y, Soeda Y, Tokai E, Wada T, Kimura I, Yanagisawa M, Sakurai T \& Sasaoka T 2008 Age-related insulin resistance in hypothalamus and peripheral tissues of orexin knockout mice. Diabetologia 51 657-667. (https://doi.org/10.1007/s00125-008-0929-8)

Vagena E, Ryu JK, Baeza-Raja B, Walsh NM, Syme C, Day JP, Houslay MD \& Baillie GS 2019 A high-fat diet promotes depression-like behavior in mice by suppressing hypothalamic PKA signaling. Translational Psychiatry 9 141. (https://doi.org/10.1038/s41398-019-0470-1)

Vigil D, Blumenthal DK, Taylor SS \& Trewhella J 2006 Solution scattering reveals large differences in the global structures of type II protein kinase A isoforms. Journal of Molecular Biology 357 880-889. (https:// doi.org/10.1016/j.jmb.2006.01.006)

Vishvanath L \& Gupta RK 2019 Contribution of adipogenesis to healthy adipose tissue expansion in obesity. Journal of Clinical Investigation 129 4022-4031. (https://doi.org/10.1172/JCI129191)

Vogler GP, Sorensen TI, Stunkard AJ, Srinivasan MR \& Rao DC 1995 Influences of genes and shared family environment on adult body mass index assessed in an adoption study by a comprehensive path model. International Journal of Obesity and Related Metabolic Disorders 19 40-45

Watanabe M, Houten SM, Wang L, Moschetta A, Mangelsdorf DJ, Heyman RA, Moore DD \& Auwerx J 2004 Bile acids lower triglyceride levels via a pathway involving FXR, SHP, and SREBP-1c. Journal of Clinical Investigation 113 1408-1418. (https://doi.org/10.1172/ JCI21025)

Weinstein LS, Shenker A, Gejman PV, Merino MJ, Friedman E \& Spiegel AM 1991 Activating mutations of the stimulatory G protein in the McCune-Albright syndrome. New England Journal of Medicine 325 1688-1695. (https://doi.org/10.1056/NEJM199112123252403)

Weisenhaus M, Allen ML, Yang L, Lu Y, Nichols CB, Su T, Hell JW \& McKnight GS 2010 Mutations in AKAP5 disrupt dendritic signaling complexes and lead to electrophysiological and behavioral phenotypes in mice. PLOS ONE 5 e10325. (https://doi.org/10.1371/ journal.pone.0010325)

Wilber JF \& Xu AH 1998 The thyrotropin-releasing hormone gene 1998: cloning, characterization, and transcriptional regulation in the central nervous system, heart, and testis. Thyroid 8 897-901. (https:// doi.org/10.1089/thy.1998.8.897)

Willis BS, Niswender CM, Su T, Amieux PS \& Mcknight GS 2011 Cell-type specific expression of a dominant negative PKA mutation in mice. PLOS ONE 6 e18772. (https://doi.org/10.1371/journal.pone.0018772)

Xu TR, Yang Y, Ward R, Gao L \& Liu Y 2013 Orexin receptors: multifunctional therapeutic targets for sleeping disorders, eating disorders, drug addiction, cancers and other physiological disorders. Cellular Signalling 25 2413-2423. (https://doi.org/10.1016/j. cellsig.2013.07.025)

Yang L, Gilbert ML, Zheng R \& Mcknight GS 2014 Selective expression of a dominant-negative type Ialpha PKA regulatory subunit in striatal medium spiny neurons impairs gene expression and leads to reduced feeding and locomotor activity. Journal of Neuroscience 34 4896-4904. (https://doi.org/10.1523/JNEUROSCI.3460-13.2014)

Yehuda-Shnaidman E, Buehrer B, Pi J, Kumar N \& Collins S 2010 Acute stimulation of white adipocyte respiration by PKA-induced lipolysis. Diabetes 59 2474-2483. (https://doi.org/10.2337/db10-0245)

Zhang Y, Proenca R, Maffei M, Barone M, Leopold L \& Friedman JM 1994 Positional cloning of the mouse obese gene and its human homologue. Nature 372 425-432. (https://doi.org/10.1038/372425a0)

Zhang JW, Klemm DJ, Vinson C \& Lane MD 2004 Role of CREB in transcriptional regulation of CCAAT/enhancer-binding protein beta gene during adipogenesis. Journal of Biological Chemistry 279 4471-4478. (https://doi.org/10.1074/jbc.M311327200)

Zhang P, Smith-Nguyen EV, Keshwani MM, Deal MS, Kornev AP \& Taylor SS 2012 Structure and allostery of the PKA RIIbeta tetrameric holoenzyme. Science 335 712-716. (https://doi.org/10.1126/ science.1213979)

Zheng R, Yang L, Sikorski MA, Enns LC, Czyzyk TA, Ladiges WC \& Mcknight GS 2013 Deficiency of the RIIbeta subunit of PKA affects locomotor activity and energy homeostasis in distinct neuronal populations. PNAS 110 E1631-E1640. (https://doi.org/10.1073/ pnas.1219542110)

Received in final form 24 April 2020

Accepted 19 May 2020

Accepted Manuscript published online 19 May 2020 https://joe.bioscientifica.com https://doi.org/10.1530/JOE-20-0035 (c) 2020 Society for Endocrinology Published by Bioscientifica Ltd. Printed in Great Britain 